\title{
EFFICACY OF FUNGITOXICANTS IN VARIOUS CONCENTRATIONS CAUSING LESION DEVELOPMENT AGAINST ALTERNARIA ALTERNATA (FRIES), KEISSLER CAUSING LEAF SPOT OF COTTON (GOSSYPIUM HIRSUTUM L.)
}

\author{
Parul Trivedi Mishra \\ Department of Botany, D.G.P.G. College, Kanpur (India) \\ Email: dr.parulmishra610@gmial.com
}

Communicated: 20.02.21

Revision : 15.03.21 \& 19.04.2021

Accepted: 23.05.2021

Published: 30.05.2021

\begin{abstract}
:
Cotton (Gossypium L.) is one of the commercial fibre yielding crop of India. It occupies a premier place in the national economy of our country due to its high-grade fibre rich in vitamins, enzymes and oil used as medicine and oil yielding cash crop. So the present investigation was done in order to check the efficacy of fungitoxicants like Agrosan G.N., Aureofungin, Captan etc. on the pathogenic effect of Alternaria alternata in causing lesion development on cotton leaves. For this, fresh healthy leaves of same age having no disease symptoms were excised and collected in polythene bags. Fungitoxicants in dilution $0.05,0.10,0.15 \ldots .$. and 0.40 percent were inoculated by spraying with an automizer at the point of injury made. Afterwards leaves were inoculated by spraying with one drop of $0.001 \mathrm{ml}$ of spore suspension at four points of leaf lamina and were kept in petridishes in moist chamber over surface sterilized bent glass rods to avoid direct contact with moist filter paper. All sets were incubated at room temperature $25 \pm 1{ }^{\circ} \mathrm{C}$. It was evident from the data that all the fungitoxicants, used in different concentration were better in performance in comparison to control. Out of the 24 fungicides and an antibiotic (Aureofungin) tested, Agrosan G.N., Captan, Ceresan and Vitavax etc. proved to be most effective by not producing any pathogenic effect. Other fungitoxicants viz. Brassicol, Calixin were found effective in producing light yellow lesions, while extensive brown spots were observed in the treatment with Bavistin.
\end{abstract}

Keywords: fungitoxicant, lesion, Gossypium, automizer, spore suspension.

\section{INTRODUCTION:}

Cotton occupies a prominent place in the national economy of our country and prosperity of millions of countries rural and urban population who depend upon a timely harvest of this vegetative fibre and oil yielding cash crop. So, in order to save this precious crop from pathogenic effect of Alternaria alternata, the given investigation was done with the given method.

\section{MATERIALS AND METHODS:}

The fungitoxicants were assessed for their protective action by observing the inhibition on the development of lesions produced by Alternaria alternata (Fries), Keissler causing leaf spot of cotton. Fresh healthy leaves of same age having no disease symptoms were taken and collected in polythene bags. Fungitoxicants in dilutions of $0.05,0.10,0.15,0.20,0.25,0.30$, 0.35 and 0.40 percent were inoculated by spreading with an automizer at the point of injury made. Fungi- toxicants were allowed to soak and dry up. Afterwards leaves were inoculated with one drop of $0.001 \mathrm{ml}$ of spore suspension at four points of leaf lamina and were kept in petridishes in moist chamber over 
surface sterilized bent glass rods to avoid direct contact with moist filter paper. All sets were incubated at room temperature $25 \pm 1^{\circ} \mathrm{C}$. The brown spot development of disease-causing leaf spot of Alternaria was evaluated after 10 days on the leaves by use of scale 0-5. Six inoculation sets on each leaf were rated and rating from three leaf discs were averaged. Sterilized distilled water was used in place of fungitoxicants sprayed in controlled sets. The different types of symptoms adduced due to pathogenic attack of Alternaria alternata on cotton leaves as leaf spot, is presented in following table A.

\section{RESULTS AND DISCUSSION:}

A dosage response was studied in different concentrations viz., 0.05 per cent, 0.10 per cent, 0.15 per cent, 0.20 per cent, 0.40 per cent and 0.60 per cent of fungitoxicants under study and pathogenic effects of pathogen, Alternaria alternate (Fries), Keissler according to the technique described under "Material and Method". The results of pathogenic effect viz., light yellow lesion (LY), Yellowish brown lesion (YB), Light brown lesion (LB), extensive brown lesion (EB), and Phytotoxic effect (PE), were observed in different concentrations of fungitoxicants alongwith control. The observations regarding the type of pathogenic effects produced are summarized in Table B and corresponding figure 1.

It is evident from the data summarized in Table $B$ and Figure 1 that all the fungitoxicants, used in different concentrations of 0.05 per cent, 0.10 per cent, 0.15 per cent, 0.20 per cent, 0.40 per cent and 0.60 per cent, were better in performance in comparison to control. Out of the 24 fungicides and an antibiotic (Aureofungin) tested, Agrosan G.N., Aureoofungin, Captan, Ceresan (Dry), Duter, Emisan-6, Foltaf 80-W, Karathane, Pancotine,
Thiram and Vitavax proved to be most effective as did not produce any pathogenic effects. Other fungitoxicants, viz., Brassicol, Calixin, and Suflex were found effective in producing the light-yellow lesions (LY), only in different concentrations of fungitoxicants and proved better in comparison to the remaining fungitoxicants tested except Brassicol, in 0.30 per cent, the higher concentration, where no pathogenic effects were showed. The phytotoxic effects (PE), were recorded in the treatment with Dithane M-45, while extensive brown spots (EB), were observed in the treatment with Bavistin, Dithane Z-78 and Ziram, in different concentrations, except light brown lesions (LB) in 0.10 per cent concentration in the treatment with Bavistin. The fungitoxicants viz; Dichlone, Ferbam, Ridomil and Spergon produced firstly the extensive brown spots (EB) in lower concentration of 0.05 per cent and thereafter in higher concentrations i.e., 0.10 per cent, 0.15 per cent, 0.20 per cent, 0.25 per cent and 0.30 per cent decreased the intensity of pathogenic effects exihibiting light brown lesions (LB), Benlate, Blitox-50 and Hexaferb shown yellowish brown lesions (YB) in different concentrations except Benlate and Hexaferb, which exhibited light yellow lesions (LY) in higher concentration of 0.30 percent and lower concentration of 0.05 percent. The results showed that as the concentrations increased, the phytotoxic effects were found decreased.

\section{REFERENCES:}

Abraham, K.J; M.R Menon and M.C Nair (1992) -comparative efficacy of fungicides in control of Alternaria blight of sunflower caused by Alternaria alternata and A. helianthi Indian Phytopathology; 23: 465 - 469.

Algarsamy, G. and R. Jeyarajan (1986)-Efficacy of fungicides against Grey mildew disease of cotton. Madras Agric. J; $7 \underline{3}$ (11) : 651 - 652 
Chopra, B. L and J. R. Sharma (1991) - Efficacy of fungicides in controlling Myrothecium leaf spot of cotton. Cotton Res. Laboratory, Ludhiana $\underline{6}(2): 128-130$.

Singh J.P., and S. Sharma (2000) - Field evaluation of fungicides for controlling Alternaria fruit rot in Tomato. Haryana. Agric. Univ. J. Res; 16: 294 - 295.

Kannan, M.S. Uthamasamy and S. MOHAN (2004): Impact of insecticides on sucking pests and natural enemy complex of transgenic cotton. Curr. Sci. $\underline{86}$ :276-279.
Maheshwari, S.K, Nazir, A. Bhat, M.A. Beij and S.D Masoodi (2007).Efficacy of fungicides against Phyliostica leaf spot of mungbean. Ann.Pl.Protec.Sci. 15:502-503.

Malani, S.S, N. Khare, N. Lakpale and Rajiv Kumar (1998) Efficacy of some fungicides against powdery mildew of grass pea(Lathyrus sativus L.)Ann.Pl. Protec. Sci. 6 : 131-135.

Chalam, M.S.V., G.Ram Chandra rao and Ch. Chinnaba (2003).Insecticide resistance and its management of cotton aphid in Guntur Distt.Ann.Pl.Protec.Sci.11:228-231. 
Table-A

Efficacy of fungitoxicants in various concentrations against pathogen Alternaria alternata (Fries.), Keissler causing leaf Spot of Cotton (Gossypium hirsutum L.)

\begin{tabular}{|c|c|c|c|c|c|c|c|c|c|c|c|c|c|}
\hline \multirow{3}{*}{\begin{tabular}{|c|} 
S. \\
No.
\end{tabular}} & \multirow{3}{*}{$\begin{array}{l}\text { Fungi- } \\
\text { toxicants }\end{array}$} & \multicolumn{12}{|c|}{ Concentrations of Fungicides } \\
\hline & & \multicolumn{2}{|c|}{0.05} & \multicolumn{2}{|c|}{0.10} & \multicolumn{2}{|c|}{0.15} & \multicolumn{2}{|c|}{0.20} & \multicolumn{2}{|c|}{0.25} & \multicolumn{2}{|c|}{0.30} \\
\hline & & జ్ّ & 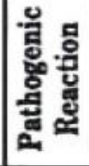 & ซึ้ & 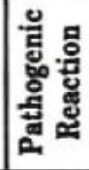 & 苟 & 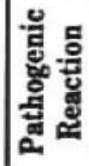 & ฐ్ّ̆ & 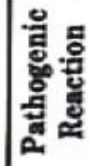 & 胥 & 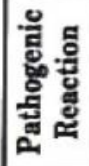 & జ్్ㄹ & 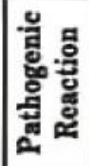 \\
\hline 1. & Agrosan G.N. & 0 & - & 0 & - & 0 & - & 0 & - & 0 & - & 0 & - \\
\hline 2. & Aureofungin & 0 & $\overline{-}$ & $\mathbf{0}$ & - & 0 & - & 0 & - & 0 & - & 0 & - \\
\hline 3. & \begin{tabular}{|l} 
Bavistin \\
\end{tabular} & 4 & EB & 3 & LB & 4 & EB & 4 & EB & 4 & EB & 4 & EB \\
\hline 4. & Benlate & 2 & YB & 2 & YB & 2 & $\mathrm{YB}$ & 2 & YB & 2 & $\overline{Y B}$ & 2 & LY \\
\hline 5. & Blitox-50 & 2 & YB & 2 & YB & 2 & YB & 2 & YB & 2 & YB & 2 & YB \\
\hline 6. & Brassicol & 1 & LY & 1 & LY & 1 & LY & 1 & LY & 1 & LY & - & $=$ \\
\hline 7. & Captan & 0 & - & 0 & $\overline{-}$ & 0 & - & 0 & - & 0 & - & 0 & - \\
\hline 8. & Calixin & 1 & LY & 1 & LY & 1 & LY & 1 & LY & 1 & LY & 1 & LY \\
\hline 9. & Ceresan (Dry) & 0 & - & 0 & - & 0 & - & 0 & $\overline{-}$ & 0 & - & 0 & $\begin{array}{ll}- \\
-\end{array}$ \\
\hline 10. & Dichlone & 4 & EB & 4 & EB & 4 & EB & 4 & EB & 3 & LB & 3 & LB \\
\hline 11. & Dithane M-45 & 5 & $\mathrm{PE}$ & 5 & $\mathrm{PE}$ & 5 & $\mathrm{PE}$ & 5 & $\mathrm{PE}$ & 5 & $\mathrm{PE}$ & 5 & $\mathrm{PE}$ \\
\hline 12. & Dithane Z-78 & 4 & EB & 4 & EB & 4 & EB & 4 & EB & 4 & EB & 4 & EB \\
\hline 13. & Duter & 0 & - & $\mathbf{0}$ & - & 0 & - & 0 & - & 0 & - & 0 & - \\
\hline 14. & Emisan-6 & 0 & - & $\mathbf{0}$ & - & 0 & - & 0 & - & 0 & - & 0 & - \\
\hline 15. & \begin{tabular}{|l|} 
Ferbam \\
\end{tabular} & 4 & EB & 3 & $\overline{L B}$ & 3 & LB & 3 & LB & 3 & LB & 3 & LB \\
\hline 16. & Foltaf $80-\mathrm{W}$ & 0 & - & 0 & - & 0 & - & 0 & 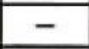 & $\begin{array}{ll}0 \\
\end{array}$ & - & 0 & - \\
\hline 17. & Hexaferb & 3 & LB & 2 & YB & 2 & YB & 2 & $\mathrm{YB}$ & 2 & YB & 2 & YB \\
\hline 18. & Karathane & 0 & - & 0 & - & 0 & $\begin{array}{ll}- \\
-\end{array}$ & 0 & $\begin{array}{lll}- & & \\
\end{array}$ & 0 & - & 0 & - \\
\hline 19. & Pancotine & 0 & - & 0 & - & 0 & - & 0 & - & 0 & - & 0 & $\begin{array}{c}- \\
\end{array}$ \\
\hline 20. & Ridomil & 4 & EB & 3 & LB & 3 & LB & 3 & LB & 3 & LB & 3 & LB \\
\hline 21. & Spergon & 4 & EB & 3 & LB & 3 & LB & 3 & \begin{tabular}{|l|} 
LB \\
\end{tabular} & 3 & LB & 3 & LB \\
\hline 22. & Suflex & 1 & LY & 1 & LY & 1 & LY & 1 & LY & 1 & LY & 1 & LY \\
\hline 23. & Thiram & 0 & - & 0 & - & 0 & - & 0 & - & 0 & - & 0 & - \\
\hline 24. & Vitavax & 0 & - & 0 & - & 0 & - & 0 & - & 0 & - & 0 & - \\
\hline 25. & Ziram & 4 & EB & 4 & EB & 4 & EB & 4 & EB & 4 & EB & 4 & EB \\
\hline 26. & \begin{tabular}{|l|} 
Control \\
\end{tabular} & 0 & - & 0 & - & 0 & - & 0 & - & 0 & - & 0 & - \\
\hline
\end{tabular}

$(-)=$ Denotes Absence, $(0)=$ Denotes Nil, $($ LY $)=$ Denotes Light Yellow lesions.

$(\mathrm{YB})=$ Denotes yellow brown lesions. $(\mathrm{LB})=$ Denotes Light Brown Lesions

$(\mathrm{ED})=$ Denotes Extensive brown lesions. $(\mathrm{PE})=$ Denotes Phytotoxic effects.

Table-B

Different kinds of Categories for the study of pathogenic symptoms produced by pathogen Alternaria alternata (Fries.), Keissler causing leaf spot of Cotton.

\begin{tabular}{|c|c|c|c|}
\hline S.No. & Grade & $\begin{array}{c}\text { Reaction and Description } \\
\text { of Symptoms }\end{array}$ & Rating \\
\hline 1. & 0 & Nil & - \\
\hline 2. & 1 & Light Yellow lesions & YY \\
\hline 3. & 2 & Yellowish brown lesions & LB \\
\hline 4. & 3 & Light brown lesions & EB \\
\hline 5. & 4 & Extensive brown lesions & PE \\
\hline 6. & 5 & Phytotoxic effects & \\
\hline
\end{tabular}




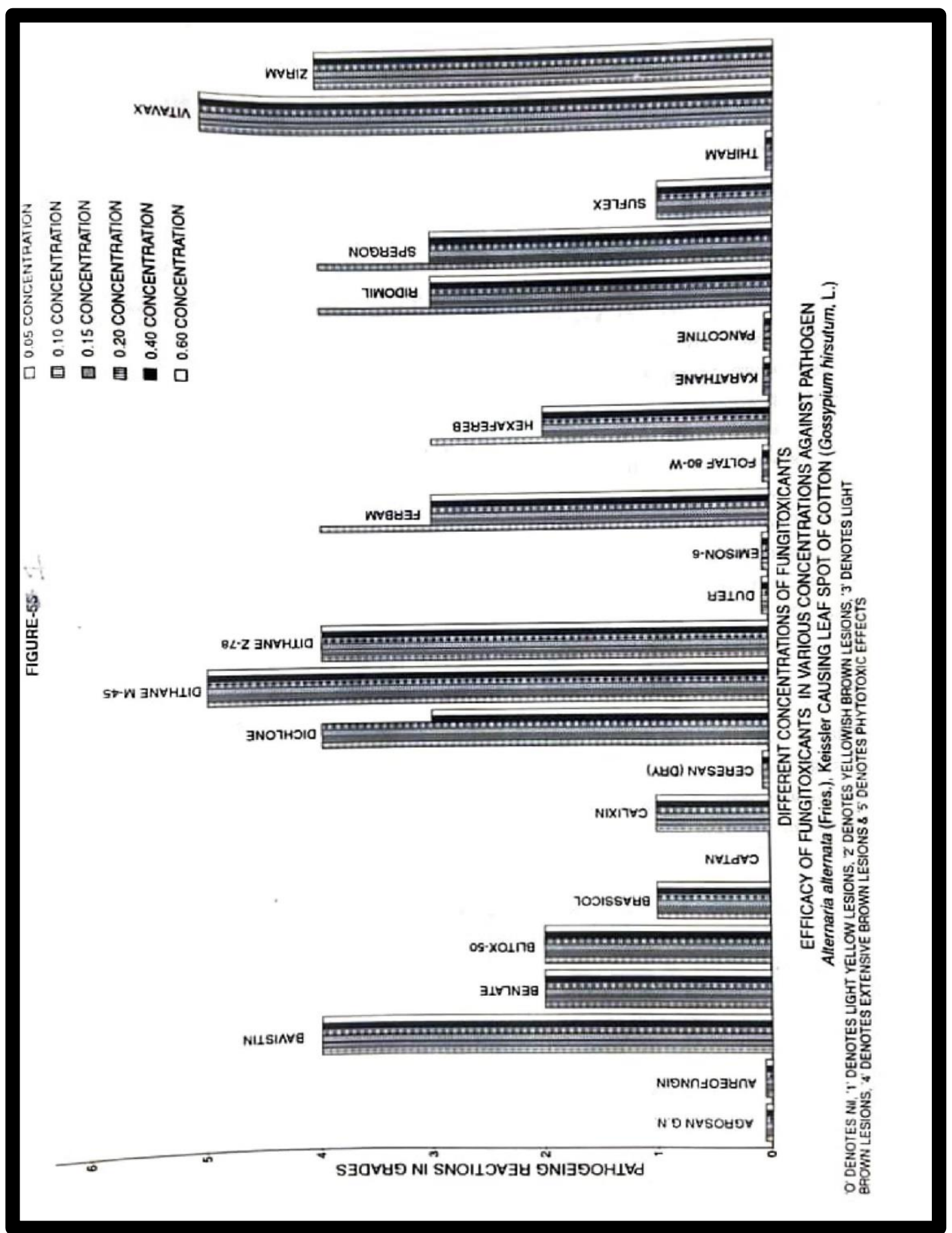

